\title{
Leadership and Decision-making Style among Women Entrepreneurs: A Case of Malaysia
}

\author{
FILZAH MD ISA \\ Associate Professor, Faculty of Business \& Law Taylors University Lakeside Campus, Malaysia. \\ Email: Filzah.MdIsa@taylors.edu.my
}

NOR AZILA MOHD NOR

Institute for Business Competitiveness, Standards and Sustainability Initiative, Universiti Utara Malaysia.

Email: azila@uum.edu.my

\section{SHAISTA NOOR}

PhD Scholar, Faculty of Business \& Law Taylors University Lakeside Campus, Malaysia. Email: shaistanoor25@gmail.com

\begin{abstract}
Women entrepreneur plays a catalytic role in economic development, as women constitute half of Malaysia's population. The contribution of women entrepreneurs in the country's economy is significant and may not ignore. Malaysia is a multicultural and multiethnic society comprised of Malays, Chinese, Indian and other local ethnics. The present study investigates the leadership and decision-making style among Malaysian women entrepreneurs. The present study adopted the qualitative research strategy, and ten women entrepreneurs are interviewed. A semi-structured interview technique is applied, and 6 Malays and 4 Chinese entrepreneurs made the study population. The result highlights that both Malay and Chinese entrepreneurs used democratic leadership styles for business management. Regarding decision-making, Malaysian women experienced failures in making the right decision. However, they considered the failure as a learning process for future decision-making. The present study will help new entrepreneurs persevere in their business ventures, and policymakers look into the best supports to enhance Malaysian women entrepreneurs' success.
\end{abstract}

Keywords: Women Entrepreneur, Decision-making Process, Leadership Styles, Malaysia.

\section{Introduction}

Entrepreneurship is considered a powerful tool for job creation and acts as a strong determinant for Malaysia's economy (Lai et al., 2010; Noor and Isa; 2020). The Malaysian government is concerned about industrial, privatization, and women involved in business to grow women entrepreneurship (Basit et al., 2020). There is a shift of women entrepreneurs in Malaysia from SMEs to immense business venture related to import and export, fashion boutique, food etc. (Alam et al., 2011; Merican and Ghani, 2016).

The Malaysian government has realized the importance of women entrepreneurs and initiated various entrepreneurial programs and policies to assist women entrepreneurs. Statistics revealed that women consist of half of population in Malaysia (MDP, 2019). Even then, the government has acknowledged the significance of women's entrepreneurship in local and international markets. Regardless, women's involvement in the various sectors is minimal compared to men, such as the aged industry (Noor et al., 2020b; Noor, Isa and Nor, 2020d). More importantly, Malaysian government is concerned for capacity building, training and soft skills of women entrepreneurs for overall business management. However, lots 
of efforts are required in various sectors for women's success. It is not only the question of equal opportunities, but it also makes economic sense as investing in women drives the economy smarter (Perianes, 2018).

Nevertheless, this national agenda's importance is that the country's overall development and progress can be associated with women entrepreneurship's success. However, limited studies have been done on qualities of successful women in business (Idris, 2008; Alam et al., 2011; Karim and Azmi, 2008; Alam et al., 2011; Fatima, Mohammad, and Joni, 2013). Despite many studies that were conducted on women entrepreneurs, there are still rooms for improvement in the findings to support the development of women entrepreneurs in Malaysia. Moreover, few direct comparisons were made regarding women entrepreneurs' decision-making and leadership styles from the Malaysian perspective. Therefore, this study aims to identify women entrepreneurs' leadership and decision-making style in Malaysia to run successfully. It is essential to reveal the prominent attributes of how they decide by leading the staff.

\section{Research Objective and Question:}

RO: To explore the leadership style and decision-making style of Malaysian women entrepreneurs.

RQ: What are the main attributes of leadership and decision-making styles of Malaysian women entrepreneurs?

\section{Literature Review}

Entrepreneurship has been studied continuously by researchers all over the world. Many definitions are proposed to explain this vital term. For instance, Hutt (1994) defines entrepreneurship as a social activity for profit generation and the term "entrepreneur," mean producers. Entrepreneurs can also be defined as self-employed, referred to those who have their own business, either small or large-scale business. Generally, the concept of entrepreneurship will be to run a business on a small scale because the owners also act as the managers who use their own money for business formation and are usually limited to the local market (Suaibah et al., 2007; Noor and Isa 2020c).

Besides, entrepreneurship also can be known as an art or process of exploring and managing their own business. In most situations, entrepreneurs ventured into a business by their efforts, have the right attitude and enthusiasm for self-employed, and have the entrepreneurial spirit that wants to pursue a career as an entrepreneur (Karim et al., 2008). We can simply state that entrepreneurship is considered as an exception activity (Spinuzzi, 2016) that can be done alone or in partnership to fulfil the desired goals by creating networking with the customer, supplier or dealers (Kuratko, 2011) which leads to revenue generation.

In all cases, entrepreneurs may not create their competitive business advantage without these assets in capturing the target market's attention. In Malaysia, various corporations and programs providing services and assistance for SMEs development specifically for women. In line with this, Amanah Ikhtiar Malaysia (AIM) provided assistance and funding to more than 200,000 women entrepreneurs in agri and service sector since 1987 from its initiation (Noor and Isa, 2020a). From a local perspective, the women force comprised $57.4 \%$ of the workforce and expected to attain the target of $59 \%$ in the upcoming years (The New Straits Times, September 24, 2018). Malaysian Cabinet set the policy that 30\% of women must be hired in a decision-making position in the business sector by 2030. It depicts the Malaysian government's support for women's entrepreneurship success. 


\section{Leadership Style}

Leadership means a way of giving the direction and motivating others and attaining the commitment of followers towards vision of leader (Kotter, 1990). Hence, leader is a person who motivate others to follow the vision to fulfill the goals. Leadership may be of various kinds such as autocratic (Vugt et al., 2004; Harms et al., 2018), parental leadership (Bellon et al., 2017), democratic (Al Khajeh, 2018; Allafchi, 2017), laissez-faire (Al Malki and Juan, 2018; Asrar-ul-Haq and Kuchinke, 2016), transactional, and transformational (Ozkan and Ozturk, 2020; Toh, et al., 2019) leadership styles. Due to their active involvement in entrepreneurship, women today have an increased leadership presence and asserted numerous leadership styles (Jang, 2015). In the 1990s, women's leadership styles gained utmost attention as researchers tried to investigate the differences between men and women leadership styles.

Women's collaborative and contributory behaviours have increased significantly while men's scores declined despite an emphasis on teamwork both in business schools and the workplace (Orhan and Scott, 2001). In many instances, emotional intelligence plays an increasingly important role where technical skills differences are minimal in importance. Without emotional intelligence, the best education, brilliant ideas accompanied by an analytical mind will not constitute a stable and productive leader. The differences in emotional intelligence between men and women could affect their leadership style (Chen,2007).

In line with this, Shane (2000) outlines entrepreneurial leadership as the creative response to new market opportunities through new business creation. However, Kuratko (2007) suggests that business creation is limiting, and entrepreneurial leadership is a unique concept combining opportunities, risk-taking beyond security, and persistent enough to follow ideas. Implicatively, entrepreneurial leadership can be treated as the fusion of three crucial concepts: entrepreneurship, entrepreneurial orientation, and entrepreneurial management. This is of course, with leadership enabling them to develop their conceptualization of entrepreneurial leadership as a process rather than individual attributes (Al Malki and Juan, 2018; Bellon et al., 2017; Jang, 2015).

\section{Decision Making}

The process of decision making is normally based on the identification and selection of the alternatives that primarily relay on decision maker values and preferences (Hussain, 2017). It is crucial to entrepreneurs as the decision-making strategy varies, especially on how they perceive, think, and react in a deeply embedded decision-making situation. Thus, thinking style will lead to how they decide. Thinking style is defined as one's preferred manner of using mental abilities to govern daily activities, including understanding, and solving problems and challenges. Thinking styles may vary depending on the conditions and demands of a given situation (Sitterly, 2001), and it can be either linear or nonlinear thinking (Downey et al., 2006). Linear thinking was based on rules, rationality, analysis, logic, reason, and cause-effect predictability (Siggelkow and Rivkin, 2007).

On the other hand, nonlinear thinking emphasizes intuition and gut feelings. It also focuses on creativity, flexibility, holistic insight, and emotion. Hence, practical thinking, planning, and problem-solving in our complex, turbulent, unpredictable, and uncertain global business environment require entrepreneurs to reach beyond merely a linear thinking platform to enhance success. While initiating a new business venture, the entrepreneur must recognize an opportunity, review available capabilities and resources, assess the markets, and allocate resources to meet common challenges (Noor et al., 2020c).

The entrepreneur's entry decisions require them to conceive a strategic framework and design steps or tactics for carrying out business strategies. Doing so will enable the entrepreneur to build the enterprise and begin to conduct business effectively. The entry decision is the single most important strategic event in the firm's life. The firm cannot perform any other strategy without it because the decision and startup strategy effects will shape its later actions. Once made, the entry decision's impact persists for life, and it is 
irreversible. Therefore, it is crucial to make the right decision starting from day one of the business operation. Having reviewed the various leadership styles and decision making process of women entrepreneurs, we will further realize their vital role in enhancing Malaysia's economic performance. Hence this study needs to explore and understand the attributes of successful Malaysian women entrepreneurs and their respective leadership styles and decision-making styles.

\section{Methodology}

The adaptation of correct methodology plays a significant role in eliminating the issues that arise while conducting the research. The present study has adopted the qualitative research strategy as it deals with marketing research methods, which stress data collection by semi-structured interview technique. However, for any research method as highlighted by (Hall et al., 2016) that philosophical underpinnings are considered very important as it depicts the researcher stance and it covers the entire schema of the researcher based on data collection and analysis technique.

Furthermore, (Clough et al., 2012) demonstrated that questions are considered the base for the entire study under investigation. Thus, the present study considers interpretivism associated with the people experience as interpretive philosophy stresses individual interaction with society (Creswell, 2012). Ten (10) women entrepreneurs from north Malaysia were interviewed. The sample size refer to (Creswell, 2012) that 5-25 respondents are enough for phenomenological study. The interview was conducted in English and Malay Language and took four months to complete.

The interviews were tape-recorded and later transcribed for analysis purposes. The interview lasted about 45 minutes to one hour. The semi-structured interviews were based on entrepreneurs ' leadership and decision-making styles and experience. Each interview question was subsequently transcribed to traceable chunks and coded by the participants for five interview questions. The study followed the Johnny Saldaña (2018) technique for data analysis. NVivo Software was used for the final data analysis (Hall et al., 2016). Table 1 depicts the interview questions.

Table 1: Interview Questions

\begin{tabular}{|c|c|}
\hline Sr.no & Interview Questions \\
\hline 1 & In your opinion, what kind of leader are you? \\
\hline 2 & What are your special leadership traits as an entrepreneur? \\
\hline 3 & How do you lead your organization? Can you share with me your vision and mission? \\
\hline 4 & $\begin{array}{l}\text { Did you ever fail in making the right business decisions? Can you share with me your } \\
\text { experience? }\end{array}$ \\
\hline 5 & How did you overcome the problems of a failed decision? \\
\hline
\end{tabular}

Table 2a \& 2b summarize the women entrepreneurs' personal and business background in detail regarding age category, marital status, number of children, education, ownership, business experience, company size, family members in business etc. 
Table 2a: Participants Personal \& Business Background

\begin{tabular}{|c|c|c|c|c|c|c|c|}
\hline \multicolumn{3}{|c|}{ Question } & \multicolumn{5}{|c|}{ Participants } \\
\hline Categories & No & types & E1 & E2 & E3 & E4 & E5 \\
\hline \multirow[t]{3}{*}{$\begin{array}{l}\text { Individual } \\
\text { Factors }\end{array}$} & 1 & $\begin{array}{c}\text { Age } \\
\text { Category }\end{array}$ & $30-39$ years & $40-59$ years & $40-59$ years & $40-59$ years & $40-59$ years \\
\hline & 2 & $\begin{array}{l}\text { Marital } \\
\text { Status }\end{array}$ & Married & Married & Married & Married & Married \\
\hline & 3 & $\begin{array}{c}\text { Do have a } \\
\text { child/children }\end{array}$ & yes 2 & yes 6 & yes 3 & yes & yes 4 \\
\hline Education & 4 & $\begin{array}{c}\text { Education } \\
\text { level }\end{array}$ & postgraduate & secondary & tertiary & $\begin{array}{c}\text { postgraduat } \\
\text { e }\end{array}$ & $\begin{array}{c}\text { postgraduat } \\
\mathrm{e}\end{array}$ \\
\hline \multirow[t]{3}{*}{$\begin{array}{c}\text { Business } \\
\text { Background }\end{array}$} & 5 & $\begin{array}{l}\text { Are you the } \\
\text { sole owner of } \\
\text { this business } \\
\text { entity? }\end{array}$ & no & yes & no & yes & yes \\
\hline & 6 & $\begin{array}{c}\text { If No, name } \\
\text { your position } \\
\text { in the } \\
\text { business. }\end{array}$ & M.D & - & others & CEO & partner \\
\hline & 7 & $\begin{array}{c}\text { This } \\
\text { Business is a: }\end{array}$ & corporation & $\begin{array}{c}\text { sole } \\
\text { proprietor }\end{array}$ & corporation & partnership & partnership \\
\hline \multirow{5}{*}{2} & 8 & $\begin{array}{c}\text { Your } \\
\text { business } \\
\text { experience in } \\
\text { the current } \\
\text { and (point to } \\
\text { that): }\end{array}$ & 11-15 years & $11-15$ years & $\begin{array}{c}\text { more than } \\
20 \\
\text { years }\end{array}$ & 6- 10 years & $1-5$ years \\
\hline & 9 & $\begin{array}{l}\text { How did you } \\
\text { involve in } \\
\text { this business? }\end{array}$ & $\begin{array}{c}\text { start on } \\
\text { business }\end{array}$ & $\begin{array}{c}\text { based on } \\
\text { personal } \\
\text { innovation } \\
\text { and } \\
\text { initiatives } \\
\end{array}$ & & $\begin{array}{c}\text { based on } \\
\text { personal } \\
\text { innovation } \\
\text { and } \\
\text { initiatives } \\
\end{array}$ & $\begin{array}{l}\text { started the } \\
\text { business } \\
\text { with } \\
\text { partner/ } \\
\text { partners } \\
\end{array}$ \\
\hline & 10 & $\begin{array}{l}\text { What is the } \\
\text { size of your } \\
\text { company? }\end{array}$ & $\begin{array}{l}\text { medium } \\
\text { (50-249 } \\
\text { employees) }\end{array}$ & $\begin{array}{c}\text { small (10- } \\
49 \\
\text { employees) }\end{array}$ & $\begin{array}{c}\text { medium } \\
(50-249 \\
\text { employees) }\end{array}$ & $\begin{array}{c}\text { small (10- } \\
49 \\
\text { employees) }\end{array}$ & $\begin{array}{c}\text { medium } \\
(50-249 \\
\text { employees) }\end{array}$ \\
\hline & 11 & $\begin{array}{l}\text { Any family } \\
\text { members } \\
\text { working in } \\
\text { the business? }\end{array}$ & yes & no & yes & yes & yes \\
\hline & 12 & $\begin{array}{c}\text { Please } \\
\text { specify your } \\
\text { relationship } \\
\text { with the } \\
\text { persons. }\end{array}$ & Sister & & $\begin{array}{l}\text { spouse and } \\
\text { children }\end{array}$ & son \& & aughter \\
\hline
\end{tabular}


Table 2b: Participant Personal and Business Background

\begin{tabular}{|c|c|c|c|c|c|c|c|}
\hline \multicolumn{3}{|c|}{ Question } & \multicolumn{5}{|c|}{ Participants } \\
\hline Categories & No & types & E6 & E7 & E8 & E9 & E10 \\
\hline \multirow[t]{3}{*}{$\begin{array}{c}\text { Individual } \\
\text { Factors }\end{array}$} & 1 & Age Category & $\begin{array}{l}40-59 \\
\text { years }\end{array}$ & $\begin{array}{l}30-39 \\
\text { years }\end{array}$ & $\begin{array}{l}30-39 \\
\text { years }\end{array}$ & $\begin{array}{c}20-29 \\
\text { years }\end{array}$ & $40-59$ years \\
\hline & 2 & Marital Status & Married & Married & Single & Married & Married \\
\hline & 3 & $\begin{array}{c}\text { Do have a } \\
\text { child/children }\end{array}$ & yes 3 & Yes, two & No & Yes, One & Yes, One \\
\hline Education & 4 & Education level & $\begin{array}{c}\text { Tertiary } \\
\text { level }\end{array}$ & Secondary & $\begin{array}{c}\text { Tertiary } \\
\text { level }\end{array}$ & $\begin{array}{c}\text { Tertiary } \\
\text { level }\end{array}$ & $\begin{array}{l}\text { Postgraduate } \\
\text { (MBA) } \\
\text { (DBA) }\end{array}$ \\
\hline \multirow[t]{7}{*}{$\begin{array}{c}\text { Business } \\
\text { Background }\end{array}$} & 5 & $\begin{array}{l}\text { Are you the } \\
\text { sole owner of } \\
\text { this business } \\
\text { entity? }\end{array}$ & No & No & No & No & Yes \\
\hline & 6 & $\begin{array}{l}\text { If No, name } \\
\text { your position in } \\
\text { the business. }\end{array}$ & $\begin{array}{l}\text { General } \\
\text { Manager }\end{array}$ & $\begin{array}{l}\text { Partner } \\
\text { and } \\
\text { manager }\end{array}$ & $\begin{array}{l}\text { Partner } \\
\text { and } \\
\text { manager }\end{array}$ & $\begin{array}{l}\text { Sharehold } \\
\text { er and } \\
\text { manager }\end{array}$ & \\
\hline & 7 & $\begin{array}{l}\text { This Business } \\
\text { is a: }\end{array}$ & $\begin{array}{c}\text { Corporatio } \\
n\end{array}$ & $\begin{array}{c}\text { Partnershi } \\
\text { p }\end{array}$ & $\begin{array}{c}\text { Partnershi } \\
\text { p }\end{array}$ & $\begin{array}{c}\text { Sole } \\
\text { proprietor }\end{array}$ & Corporation \\
\hline & 8 & $\begin{array}{l}\text { Your business } \\
\text { experience in } \\
\text { the current and } \\
\text { (point to that): }\end{array}$ & $\begin{array}{l}\text { More than } \\
20 \text { years }\end{array}$ & $\begin{array}{c}11-15 \\
\text { years }\end{array}$ & $\begin{array}{l}6 \text { to } 10 \\
\text { years }\end{array}$ & $\begin{array}{l}6 \text { to } 10 \\
\text { years }\end{array}$ & $11-15$ years \\
\hline & 9 & $\begin{array}{l}\text { How did you } \\
\text { involve in this } \\
\text { business? }\end{array}$ & $\begin{array}{c}\text { Based on } \\
\text { personal } \\
\text { innovation } \\
\text { and } \\
\text { initiatives }\end{array}$ & $\begin{array}{l}\text { Started } \\
\text { with } \\
\text { partner }\end{array}$ & $\begin{array}{c}\text { Based on } \\
\text { personal } \\
\text { innovation } \\
\text { and } \\
\text { initiatives }\end{array}$ & $\begin{array}{l}\text { With the } \\
\text { help of } \\
\text { husband }\end{array}$ & $\begin{array}{c}\text { Based on } \\
\text { personal } \\
\text { innovation } \\
\text { and } \\
\text { initiatives } \\
\end{array}$ \\
\hline & 10 & $\begin{array}{c}\text { What is the size } \\
\text { of your } \\
\text { company? }\end{array}$ & $\begin{array}{l}\text { Medium } \\
(50-249)\end{array}$ & Small & $\begin{array}{l}\text { Micro (1- } \\
9 \text { staff)1 }\end{array}$ & $\begin{array}{c}\text { Medium } \\
(50-249)\end{array}$ & $\begin{array}{l}\text { Micro (1 - } 9 \\
\text { employees) }\end{array}$ \\
\hline & 11 & $\begin{array}{c}\text { Any family } \\
\text { members } \\
\text { working in the } \\
\text { business? }\end{array}$ & Yes & No & No & Yes & No \\
\hline & 12 & $\begin{array}{c}\text { Please specify } \\
\text { your } \\
\text { relationship } \\
\text { with the } \\
\text { persons. } \\
\end{array}$ & Children & & & & band \\
\hline
\end{tabular}

\section{Discussion}

The interview conducted to get the holistic view of women entrepreneurs (Malays and Chinese) leadership styles to leading and managing the centers. For this purpose, coded data from interviewed participants were cross-referenced with another participant to highlight the matches and differences of their views. This step is for continuous comparison to develop fewer themes for a research question (Crotty, 1998). Below mentioned the discussion. 
Table 3. Kind of Leader

\begin{tabular}{|l|l|c|}
\hline Interview Questions & Themes & No of Participants \\
\hline \multirow{2}{*}{$\begin{array}{l}\text { In your opinion, what kind of leader } \\
\text { are you? }\end{array}$} & Democratic & $8(6-\mathrm{M} 2-\mathrm{C})$ \\
\cline { 2 - 3 } & Democratic and Autocratic. & $1(\mathrm{C})$ \\
\cline { 2 - 3 } & Participative & $1(\mathrm{C})$ \\
\hline
\end{tabular}

Note: $(\mathrm{M}=$ Malay $\mathrm{C}=$ Chinese $)$

The study's findings concerning leadership style show that majority of the respondent is mainly a democratic leader. While one of participant highlighted democratic and in some instances, she acts as an autocratic leader (Refer to Table 3). Overall, both Malay and Chinese women entrepreneurs skewed towards a democratic leadership style. The feedback of the participants are as follows:

"Sometimes we think that our idea is correct, but actually our staff' ideas are much better, then we should consider those ideas"(E1)

"I lead my organization by providing good examples. I give advice to my children in managing the company. I inculcate Islamic values in the organization, for instance, I pray tahajud/istikharah to ask Allah's assistance in making the right decision" (E6)

Table 4. Leadership Traits

\begin{tabular}{|l|l|c|}
\hline What are your special & Persistence & 9 (6-M 3-C) \\
\cline { 2 - 3 } $\begin{array}{l}\text { leadership traits as an } \\
\text { entrepreneur? }\end{array}$ & Sincerity & $9(6-\mathrm{M} 3-\mathrm{C})$ \\
\cline { 2 - 3 } & Passion & $9(6-\mathrm{M} \mathrm{3-C})$ \\
\cline { 2 - 3 } & Perseverance & $9(6-\mathrm{M} 3-\mathrm{C})$ \\
\cline { 2 - 3 } & Risk taker & $8(5-\mathrm{M} 3-\mathrm{C})$ \\
\cline { 2 - 3 } & Seek for feedback & $8(5-\mathrm{M} 3-\mathrm{C})$ \\
\cline { 2 - 3 } & Integrity & $7(5-\mathrm{M} 2-\mathrm{C})$ \\
\hline
\end{tabular}

Note: $(\mathrm{M}=$ Malay $\mathrm{C}=$ Chinese $)$

Based on the interviews, most women entrepreneurs seemed to have two most important entrepreneurial traits that are considered crucial to their business success (Refer to Table 4). The two traits are persistent and risk-taking. The feedback from participants are as follows:

"I am persistent, and a risk-taker and I drink tea to keep myself alert and active"(E7).

"An entrepreneur must be able to be risk-taker, endure, smell opportunities and act fast" (E8)

"My special traits are persistency, risk-taking and feedback-seeking" (E9)

Table 5. Business Operation

\begin{tabular}{|l|l|c|}
\hline How do you lead your & Believe in teamwork & $8(4-\mathrm{M} 4-\mathrm{C})$ \\
\cline { 2 - 3 } $\begin{array}{l}\text { organization? Can you share } \\
\text { with me your vision and } \\
\text { mission? }\end{array}$ & Best management consultant & $8(5-\mathrm{M} \mathrm{3-C})$ \\
\cline { 2 - 3 } & Islamic values in organisations & $6(6-\mathrm{M})$ \\
\cline { 2 - 3 } & Proper SOPs & $6(3-\mathrm{M} 3-\mathrm{C})$ \\
\cline { 2 - 3 } & Help of Malay Entrepreneurs & $6(6-\mathrm{M})$ \\
\cline { 2 - 3 } & $\begin{array}{l}\text { Introduction of Malaysian } \\
\text { products abroad }\end{array}$ & $5(2-\mathrm{M} 3-\mathrm{C})$ \\
\hline
\end{tabular}

Note: $(\mathrm{M}=$ Malay $\mathrm{C}=$ Chinese $)$ 
This study showed different entrepreneurs have different ways of operating their business. To succeed, the majority of the entrepreneurs prepared the Standard Operation Procedures (SOP) to manage and align their business operating correctly (Refer to Table 5).

"We need to have SOP because if we do not have SOP, we cannot apply for GMP, we also cannot obtain any certification, for example, Halal certificate, and because of that, SOP is important to my company" (E3).

"It is important to have SOP because we can follow it for a long time to standardize our business operation" (E9).

Table 6. Decision Making Challenges

\begin{tabular}{|l|l|c|}
\hline Did you ever fail in making & Hiring mistakes & 8(5-M 3- C) \\
\cline { 2 - 3 } $\begin{array}{l}\text { good business decisions? Can } \\
\text { you share with me your } \\
\text { experience? }\end{array}$ & Less profit making & 6(3-M 3- C) \\
\cline { 2 - 3 } & $\begin{array}{l}\text { Chosen wrong product } \\
\text { setting }\end{array}$ & $5(2-\mathrm{M} 3-\mathrm{C})$ \\
\cline { 2 - 3 } $\begin{array}{l}\text { How did you overcome the } \\
\text { problems of a failed decision? }\end{array}$ & \begin{tabular}{l} 
SOPs for hiring \\
\cline { 3 - 3 }
\end{tabular} & $\begin{array}{l}\text { Performance measurement } \\
\text { system }\end{array}$ \\
\cline { 2 - 3 } & Business networking & 8(1-M 3-C) \\
\cline { 2 - 3 } & Market survey & 6(2-M 4- C) \\
\hline
\end{tabular}

Note: $(\mathrm{M}=$ Malay $\mathrm{C}=$ Chinese $)$

Referring to making a decision, every entrepreneur, Malay and Chinese, has experienced failure to make a good decision. They, however, considered the failure as a learning process for future decision-making purposes (Refer to Table 6). The verbatim from participants are as follows:

"Actually we need to remember that wrong decision making will provide us with new knowledge, for example, we can learn why our product is not saleable” (E3).

"I made the wrong decision regarding pricing strategy, and whenever you talk too much you sometimes will make a mistake; therefore it is better for you to listen and be a good listener to make you a better decision maker" (E4).

The findings revealed several similarities of responses from the Malay and Chinese entrepreneurs, such as persistent (M-6, C-3) and risk-taking traits (5-M 3-C), democratic leadership style (6= M 2=C), and the majority of the entrepreneurs' failure (5-M 3- C) to make the right decision. The findings relate to previous literature that the entrepreneur must find an opportunity and go properly look into available resources, market accessibility and allocation to resources to fulfill the desire goal. The right decision making helps the entrepreneur to conceive a strategic framework and imagine the steps or tactics for carrying out the strategy in proper way (Brouthers and Hennart, 2007; Thurik and Wennekers, 2011; Noor et al., 2020c; Asrar-ul-Haq and Kuchinke, 2016; Al Malki and Juan, 2018). Furthermore, Both Malay and Chinese entrepreneurs believe in SOP to ensure higher success. Similarly, they measure business operation effectiveness differently according to their needs and expected outcomes, and finally, they use various types of decision-making strategies suitable for their business context depending upon the priority. Women entrepreneurs sometimes failed to make a decision related to 1) marketing, i.e. product choice and marketing strategy 2) HRM, i.e. hiring new employee 3) Financial, i.e. less profitability 4) Performance measurement system 4) Business networking to expand skills and resources. However, they overcome the decision failure by 1) adopting SOP in the company, 2) conducting marketing survey to understand the 
customer needs, 3) adopting marketing strategies 4) proper budgeting and cash flow statements 5) setting the quality standards and networking. The findings are in tandem with previous literature, as Sarasvathy (2001) describes two kinds of decision-making modes in business settings, causation, and effectuation. Causation is described as using analysis and estimation techniques to discover the market situation and need of customers. Thus, causal reasoning stresses what needs to be done to fulfil the goals and effectuation focuses on the entrepreneurial decision making in conditions of high uncertainty when the future cannot be predicted through statistical inferences (Downey et al., 2006; Hussain, 2017; Siggelkow and Rivkin, 2007; Sitterly, 2001).

\section{Theoretical Justification}

The underlying theory for this study is RBV theory, which has been recognized as one of the most influential and cited theories in contemporary strategic management research, was developed by Wernerfelt (1984), Rumelt (1984) and, Barney (1986) in the mid-1980s. It adopts an inward approach by focusing on a firm's internal strengths and weaknesses. Particularly, it helps explain under which conditions that a firm's resources can generate sustained competitive advantages (Barney, 1991). RBV suggests that, if a firm is to achieve sustained competitive advantages, it must possess bundles of strategically relevant resources and capabilities (Barney, 1991) that are valuable, rare, imperfectly imitable, and non-substitutable (VRIN). Within the field of entrepreneurship, scholars (Alvarez \& Busenitz, 2001; Chandler \& Hanks, 1994; Connor, 1991) have primarily acknowledged that entrepreneurship is an intricate part of the resource-based framework. Nowadays, a growing body of research has leveraged the RBV tenets to understand the determinants of entrepreneurial venture performance (Kellermanns, Walter, Crook, Kemmerer, \& Narayanan, 2014). For instance, the study by Alvarez and Busenitz (2001) extends the RBV to current research on entrepreneurship by introducing both; i) entrepreneurial recognition, defined as "the recognition of opportunities and opportunity-seeking behavior" , and ii) "the process of combining and organizing resources" as heterogeneous resources that transform inputs into heterogeneous outputs that lead to sustainable competitive advantages. In addition, Wiklund and Shepherd (2003) conclude that through a firm's entrepreneurial orientation, a measure of the way the firm is organized to discover and exploit opportunities that knowledge-based resources transformed into enhanced firm performance.

\section{Conclusion}

The present study highlights the factors necessary for women entrepreneurs' success, specifically in decision-making and leadership related issues. In doing business, they sometimes made the wrong decision, but they learned from their mistakes to excel further. The leadership styles and decision making styles of Malays and Chinese women entrepreneurs in Malaysia are not different. It may be because Malaysian women entrepreneurs' business culture is influenced by the country's unique attributes comprising multiethnic, multi-cultures, and multi religions people who live harmoniously with caring and sharing attitudes. The country's living culture reflects the business culture of its entrepreneurs, especially women, who seem to be more caring, meticulous, and empathetic than men. The study results implicate that women entrepreneurs' leadership and decision-making styles could be affected by their distinctive personal traits, business experience, business types, and business environment where they work. More importantly, women's personal factors seem to play a pivotal role in their business success in all industries. Among the individual factors that the participants mentioned are self-confidence, persistence, strong willpower, and risk-taking. These factors, however, can be embedded within the women entrepreneurs through short courses, business workshops, training programs, mentoring programs or even long-term courses. These positive factors, coupled with business experience and the right business choice and environment, can lead to a sustainable business in the marketplace. From the study also, two necessary supports play a substantial role in the women entrepreneurs' business success: government support and spouse/family support. Both factors could further enhance entrepreneurs' leadership and decision making effectiveness. Future studies may be done using a quantitative approach to find the most trends of women entrepreneurs' leadership and 
decision-making style. Since this research focuses on Malaysia's northern region, further research should explore women entrepreneurs of different regions and areas, and extend the entrepreneurs' leadership and decision-making styles into a more in-depth study such as leadership and decision-making strategies, issues and challenges.

\section{Acknowledgement}

This research will not be possible without the Ministry of Higher Education Malaysia (MOHE), the technical support from RIMC-UUM and Institute for Business Competitiveness, Standards and Sustainability Initiative of UUM. Therefore, we would like to express our gratitude to both MOHE and UUM for giving us this meaningful research opportunity. We would also like to acknowledge the contribution of Dr Siti Norezam Othman and Dr Cheng Wei Hin in this research project. Our sincere prayers to the improvement of their health.

\section{References}

Alam, S. S., Jani, M. F., \& Omar, N. A. (2011). An empirical study of success factors of women entrepreneurs in southern region in Malaysia. International Journal of Economics and Finance, 3(2). https://doi.org/10.5539/ijef.v3n2p166.

Allafchi, N. (2017). Effect of democratic leadership style on management of communication with customers in Melli Banks of Hamedan. International Journal of Cultural and Social Studies, 3(2), 168179.

Al Khajeh, E. H. (2018). Impact of leadership styles on organisational performance. Journal of Human Resources Management Research, 2018, 1-10.

Al Malki, M., \& Juan, W. (2018). Impact of laissez-faire leadership on role ambiguity and role conflict: Implications for job performance. International Journal of Innovation and Economic Development, 4(1), 29-43.

Asrar-ul-Haq, M., \& Kuchinke, K. P. (2016). Impact of leadership styles on employees' attitude towards their leader and performance: Empirical evidence from Pakistani banks. Future Business Journal 2 , 2016, 54-64.

Alvarez, S. A., \& Busenitz, L. W. (2001). The entrepreneurship of resource-based theory. Journal of Management, 27(6), 755-775.

Barney, J. (1986). Strategic factor markets: Expectations, luck, and business strategy. Management Science, 32, 1231-1241.

Barney, J. (1991). Firm resources and sustained competitive advantage. Journal of Management, 17(1), 99120.

Basit, A., Hassan, Z., \& Sethumadhavan, S. (2020). Entrepreneurial success: Key challenges faced by Malaysian women entrepreneurs in 21st century. International Journal of Business and Management, 15(9), 122. https://doi.org/10.5539/ijbm.v15n9p122.

Bellon, E. O., Ngware, M. W., \& Admassu, K. (2017). The role of parental leadership in academic performance: A case of pupils in the free primary education program in Kenya. Education and Urban Society, 49(1), 110-130.

Brouthers, K. D., \& Hennart, J. (2007). Boundaries of the firm: Insights from international entry mode research. Journal of Management, 33(3), 395-425. https://doi.org/10.1177/0149206307300817.

Chandler, G. N., \& Hanks, S. H. (1994). Market attractiveness, resource-based capabilities, venture. strategies, and venture performance. Journal of Business Venturing, 9, 331- 350.

Chen, M. (2007). Entrepreneurial leadership and new ventures: Creativity in entrepreneurial teams. Creativity and Innovation Management, 16(3), 239-249. https://doi.org/10.1111/j.14678691.2007.00439.x.

Clough, P., and Nutbrown, C. (2012). A Student's Guide to Methodology: Justifing Enquiry (3rd Ed.). London: Sage. 
Conner, K. R. (1991). An historical comparison of resource-based theory and five schools of thought within industrial organization economics: Do we have a new theory of the firm? Journal of Management, 17, $121-154$

Creswell, J. W., \& Poth, C. N. (2012.). Qualitative inquiry \&amp; research design : choosing among five approaches. Retrieved from https://in.sagepub.com/en-in/sas/qualitative-inquiry-and-researchdesign/book246896.

Crotty, M. (1998) The foundations of social research: Meaning and perspective in the research process. Thousand Oaks, CA: Sage Publications.

Downey, L., Papageorgiou, V., \& Stough, C. (2006). Examining the relationship between leadership, emotional intelligence and intuition in senior female managers. Leadership \& Organization Development Journal, 27(4), 250-264. https://doi.org/10.1108/01437730610666019

Fatimah-Salwa, A. H., Mohamad-Azahari, A., \& Joni-Tamkin, B. (2013). An empirical evidence from Malaysia: What makes the Muslim entrepreneurs succeed? International Journal of Economics and Finance, 5(7). https://doi.org/10.5539/ijef.v5n7p94.

Hall, E., Chai, W., \& Albrecht, J. A. (2016). A Qualitative Phenomenological Exploration of Teachers'Experience With Nutrition Education. American Journal of Health Education, 47(3), 136148. https://doi.org/10.1080/19325037.2016.1157532.

Harms, P. D., Wood, D., Landay, K., Lester, P. B., \& Lester, G. V. (2018). Autocratic leaders and authoritarian followers revisited: A review and agenda for the future. The Leadership Quarterly, 29(1), 105-122.

Hussain, S. T., Abbas, J., Lei, S., Haider, M. J., \& Akram, T. (2017). Transactional leadership and organisational creativity: Examining the mediating role of knowledge sharing behaviour. Journal Cogent Business and Management, 4(1), 1-12.

Hutt, G. (1994). Incorporating quality performance objectives into performance appraisal systems. The TQM Magazine, 6(1), 8-12. https://doi.org/10.1108/09544789410052688.

Idris, F., \& Mohd Ali, K. A. (2008). The impacts of leadership style and best practices on company performances: Empirical evidence from business firms in Malaysia. Total Quality Management \& Business Excellence, 19(1-2), 165-173. https://doi.org/10.1080/14783360701602130.

Jang, Y. (2015). Effects of parental leadership and verbal control modes on preschool children's leadership. The Korean Journal of Community Living Science, 26(2), 249-259.

Karim, S. A., \& Azmi, I. A. G. (2008). Muslim women entrepreneurs: A study on success factors. In the Proceeding of National Islamic Entrepreneur Seminar II, Islamic Studies Academy, Universiti Malaya, on 15 October 2008.

Kellermanns, F., Walter, G., Crook, R. T., Kemmerer, B., \& Narayanan, V. (2014). The resource-based view in entrepreneurship: A content-analytical comparison of researchers' and entrepreneurs' views. Journal of SME Management, 54(1), 26-48.

Kuratko, D. F. (2011). Entrepreneurship theory, process, and practice in the 21st century. International Journal of Entrepreneurship and Small Business, 13(1), 8. https://doi.org/10.1504/ijesb.2011.040412.

Lai, K., Nathan, R., Tan, K., \& Chan, B. (2010). Effect of innovation to the success of female entrepreneurs. Journal of Innovation Management in Small and Medium Enterprise, 114. https://doi.org/10.5171/2010.369877.

Malaysia Demographics Profile (2019). Retrieved March 30, 2020, from https://www. index mundi.com/malaysia/demographics_profile.html.

Merican, J., \& Ghani, S. (2016). Advancing the women agenda: Where is Malaysia at now? Retrieved April 1, 2020, from http://www.leaderonomics.com.

Noor, S., \& Md. Isa, F. (2020a). Entrepreneurial opportunities for Malaysian women in ageing care industry. Social and Management Research Journal, 17(2), 83. https://doi.org/10.24191/smrj.v17i2.10515.

Noor, S., Isa, F. M., Hossain, M. S., \& Shafiq, A. (2020b). Ageing care centers: Mediating role of quality care and proactive environment. Journal of Population and Social Studies,28(4), 324347. https://doi.org/10.25133/jpssv28n4.022. 
Noor, S., \& Isa, F. M. (2020c). Contributing factors of women entrepreneurs' business growth and failure in Pakistan. International Journal of Business and Globalisation, 25(4), 503. https://doi.org/10.1504/ijbg.2020.109115.

Noor, S. Isa, F.M, Nor. Mohd (2020d) "Ageing Centre women entrepreneurs: A Silver Bullet for Ageing Tsunami in Malaysia” 12:1 (2020) 51-62| www.sainshumanika.utm.my | e-ISSN ISSN: 22896996.

Ozkan, O., \& Ozturk, I. (2020). Impact of organisational culture and leadership styles on employee performance: A research study on the banking industry. Research Journal of Business and Management, 7(1), 45-55.

Orhan, M., \& Scott, D. (2001). Why women enter into entrepreneurship: An explanatory model. Women in Management Review, 16(5), 232-247. https://doi.org/10.1108/09649420110395719

Perianes, M. B. (2018). Investing in women is smart economics. Retrieved April 1, 2020, from https://medium.com/datadriveninvestor/investing-in-women-is-smrteconomics-97f 3ee6446ef.

Rumelt, R. P. (1987). Theory, strategy, and entrepreneurship. In D. Teece (Ed.), The competitive challenge (pp. 556-570). Cambridge, MA: Ballinger.

Saldaña, J. (2018). Writing Autoethnography. Writing $\quad$ Qualitatively, 156 175. https://doi.org/10.4324/9781351046039-14.

Sarasvathy, S. D. (2001). Causation and effectuation: Toward a theoretical shift from economic inevitability to entrepreneurial contingency. The Academy of Management Review, 26(2), 243. https://doi.org/10.2307/259121.

Shane, S., \& Venkataraman, S. (2000). The promise of entrepreneurship as a Field of research. Academy of Management Review, 25(1), 217-226. https://doi.org/10.5465/amr.2000.2791611

Siggelkow, N., \& Rivkin, J. W. (2007). Coupled search processes: Why is it so difficult to find that organizational design matters? SSRN Electronic Journal. https://doi.org/10.2139/ssrn.1001704

Spinuzzi, C. (2016). Introduction to the special issue on entrepreneurship communication. IEEE Transactions on Professional Communication, 59(4), 316322. https://doi.org/10.1109/tpc.2016.2607803.

Sitterly, C. (2001). More women succeed as Business Owners. Sitcom. Inc. Retrieved September 10, 2005, from http://www.sitcom.com/women/succeed.html.

The New Straits Times (September 24, 2018). Government wants 30 percent women in decision making positions by 2030. Retrieved Aril 1, 2020, from https://www. ggogle.com /amp/s/www.nst.com.my/node/414388/amp.

Thurik, R., \& Wennekers, S. (2004). Entrepreneurship, small business and economic growth. Journal of Small Business and Enterprise Development, 11(1), 140149. https://doi.org/10.1108/14626000410519173.

Toh, P. S., Liew, W. J., Rahim, I. H. A., \& Stephen, S. (2019). Transformational and transactional leadership styles towards organisational commitment in the hotel industry. Journal of Tourism, Hospitality, and Environment Management, 4(17), 34-45.

Vugt, M. V., Jepson, S. F., Hart, C. M., \& Cremer, D. D. (2004). Autocratic leadership in social dilemmas: A threat to group stability. Journal of Experimental Social Psychology, 40(1), 1-13.

Wernerfelt, B. (1984). A resource-based view of the firm. Strategic Management Journal, 5, 171- 180.

Wiklund, J., \& Shepherd, D. (2003). Knowledge-based resources, entrepreneurial orientation, and the performance of small and medium-sized businesses. Strategic Management Journal, 24(13), 13071314. 